\title{
Mining in Southeast Sulawesi and Central Sulawesi: Shadow Economy and Environmental Damage Regional Autonomy Era in Indonesia
}

\author{
$1^{\text {st }}$ Abdul Kadir \\ Dept. of Administration \\ Universitas Halu Oleo \\ Kendari, Indonesia \\ habdulkadir64@yahoo.com
}

\author{
$2^{\text {nd }}$ Eka Suaib \\ Dept. of Political Science \\ Universitas Halu Oleo \\ Kendari, Indonesia \\ ekasuaib1966@gmail.com
}

\author{
$3^{\text {rd }}$ La Husen Zuada \\ Dept. Goverment Science \\ Universitas Tadulako \\ Palu, Indonesia \\ husenzuadaui@gmail.com
}

\begin{abstract}
This article tells about the practice of shadow economy and environmental damage in mining activities in Southeast Sulawesi and Central Sulawesi. Natural assets contained in these two regions, especially the mine, attracted the attention of investors to invest their capital. The presence of mining companies has been going on for a long time. Before regional autonomy, state-owned mining companies, foreignowned private companies and national entrepreneurs were the biggest holders of mining areas in Southeast Sulawesi and Central Sulawesi. In the of regional autonomy era, mining exploration is no longer monopolized by government companies (state) and large-scale foreign companies, but increasingly competitive after the importance of medium-scale private investors. Regional autonomy plays a role in opening the entry of mining investors from the private sector. Mining business licenses (IUPs) issued by local governments in Southeast Sulawesi and Central Sulawesi have experienced a boom, but have left a problem. The Ministry of Energy of Human Resources released mining activities in Indonesia in two states, namely clear and clean (CNC) and non Clear and Clean (non$\mathrm{CNC}$ ). In practice, in the field of mining companies with $\mathrm{CNC}$ status, they often carry out illegal practices in Indonesian mining regulations. Likewise, mining companies that are declared nonCNC still carry out production activities in secret (shadow economy). This practice has resulted in state losses, such as not registering taxes, loss of mining companies' social responsibility to society and environmental damage.
\end{abstract}

Keywords: mining, shadow economy, environmental damage, regional autonomy

\section{INTRODUCTION}

Indonesia is a country that stores abundant natural resources, especially in the mining sector. The United States

${ }^{1}$ Foreign companies refer to two things, namely: first, global scale companies owned / established by foreign parties (overseas); second, national scale companies but the
Geological Survey (USGS) notes that Indonesia is ranked 6th as the world's mining producer. Various types of mining include petroleum, natural gas, minerals and coal contained in Indonesia's sovereign territory. The potential of Indonesian oil mines is ranked 25th in the world, while mineral mining is ranked in the world's top ten. The availability of mineral mines in Indonesia, including: $2.3 \%$ of world gold reserves (rank 7), tin $8.1 \%$ (rank 5), copper $4.1 \%$ (rank 7), and nickel 2.1\% (rank 8) [1].

Accordingly, in 2015, based on data from the Ministry of Energy and Human Resources (ESDM), Indonesia has total available and estimated reserves, copper (20 billion tons), tin (5.2 billion tons), nickel (4.8 billion) tons) and gold (111 billion tons). With such a profile, Indonesia is a very promising country for the mining industry, especially mineral and coal mining. A number of large companies - such as PT. Freeport Indonesia, PT. Newmont, PT. International Nickel Indonesia INCO / PT. Vale Indonesia Tbk - is a foreign company ${ }^{1}$ that carries on mining activities in Indonesia.

Besides foreign companies, a number of national companies owned by the state (BUMN) are involved in mining activities. PT. Timah, PT. Indonesia Asahan Aluminum (INALUM) and PT. Aneka Tambang (ANTAM) is a state-owned company that holds a number of mining concessions in Indonesia. In addition, a number of large-scale privately owned mining companies (private) that hold mining rights are PT. Bumi Resource Tbk is owned by the Bakri family and PT Toba Bara Sejahtera Group is owned by Luhut Binsar Panjaitan. These two companies carry out a lot of mining activities in the regions of Sumatra, Kalimantan and Sulawesi. From the history of its founding and birth, a number

establishment and majority of shares are owned by foreigners. 
of large-scale mining companies have existed since the days of the old and new order, except PT Toba Bara Sejahtera which stood in the era of regional autonomy.

In the era of regional autonomy, the number of mining companies has increased in line with the granting of authority to regions (regencies / cities) to manage their regional potential. This authority is fully utilized by local governments, the private sector and the community to increase revenue. For local governments, in an effort to increase local revenue, granting a mining business permit is a solution adopted to bring investment, increase taxes and create employment. On the other hand, the private sector (entrepreneurs) welcomed regional autonomy by establishing companies and mining business licenses to increase wealth. Do not miss the community into labor in the mining sector and small and medium businesses around the mine site.

The Publish What Your Pay (PWYP) report said that in the era of regional autonomy, Indonesia experienced a boom in Minerba licensing. In 2001, at the beginning of regional autonomy, mining permits were rolled for around 750 , then in 2010 the number of licenses increased to more than 10 thousand. PWYP mentions that this phenomenon occurs due to the unsynchronization of policies during the transition period from the era of centralism to regional autonomy (decentralization), resulting in uncontrolled licensing rates. Simultaneously, in the regions, various mining problems began to emerge, such as: mining conflicts, environmental damage, permits that violate laws and regulations, tax evasion, $\mathrm{KKN}$ at the local level, and others.

Central Sulawesi and Southeast Sulawesi are areas where mining activities take place. In Central Sulawesi, in 2016 based on data from the Ministry of Energy and Mineral Resources, the number of IUPs was 437. This number is smaller, compared to Southeast Sulawesi, where in 2015 the number of IUPs reached 527. The large potential of the Central Sulawesi and Southeast Sulawesi are areas where mining activities take place. In Central Sulawesi, in 2016 based on data from the Ministry of Energy and Mineral Resources, the number of IUPs was 437. This number is smaller, compared to Southeast Sulawesi, where in 2015 the number of IUPs reached 527. The large potential of the mining sector in these two regions is indicated by the establishment of smelter factories in the Regency Morowali (Central Sulawesi) and Konawe District (Southeast Sulawesi). However, the high level of mining activity in the two provinces has caused a number of irony, including environmental damage and the company's illegal practice of selling mining products. Departing from that, this paper will answer the question of what forms of shadow economy practices in mining management in Southeast Sulawesi and Central Sulawesi? Second, what impact does this practice have?

\section{THEORETICAL REVIEW}

\section{A. Shadow Economy}

The concept of shadow economy is often equated with black economy and underground economy [2]. [3] mentions that shadow economy is the economic activity and income derived from those who evade or avoid government regulations, taxation or observation. Meanwhile, undergoing economy as a production and sale of legal goods and services, the activities are not recorded and registered in tax records, do not refer to labor regulations and are not included in the social security system [2]. Referring to Chotim's opinion, there seems to be no difference between shadow economy and underground economy. This contrasts with [4] explanation in his book The Hidden Enterprise Culture: Entrepreneurship in the Underground Economy.

In understanding the underground economy, Williams he called the underground economy conventionally constructed as something subordinate to other economic categories (formal economy) and characterized by negative characteristics, such as unstructured, informal, disorganized, abnormal, hidden, and illegal. This explanation gives meaning that the underground economy is an informal economic activity carried out illegally. Thus, the underground economy does not touch on formal economic activities that are carried out in a non-transparent manner. In this explanation, this is the limitation of the undergroud economy theory to explain mining practices that have permits (formal), but in their operations (sales and tax reporting) are not done transparently (taking place illegally). In order to understand hidden economic activities both legally and illegally, the shadow economy theory provides broader scope and more detailed explanations. [4] cite Lippert and Walker make a classification of the practice of shadow economy as set out in table 1 .

Based on the table above, shadow economy includes legal and illegal economic transactions that are carried out in a nontransparent manner in order to avoid taxation and regulation of legislation. Schneider and Williams said economic shadows include unreported income from the production of legal goods and services, both from monetary or barter transactions - and include all productive economic activities which would generally be taxed if reported to state authorities (tax) [4]. It was further mentioned that the practice of shadow economy was deliberately carried out for reasons: 1 ). to avoid payment of income, value added or other taxes; 2). to avoid payment of social security contributions; 3 ). to avoid having to meet certain legal labor market standards, such as minimum wages, maximum hours of work, safety standards, etc; and 4). to avoid compliance with certain administrative obligations. 
TABLE I. TAXONOMI OF TYPES OF UNDERGROUND ECONOMIC ACTIVITIES

\begin{tabular}{|c|c|c|c|c|}
\hline $\begin{array}{l}\text { Type of } \\
\text { activity }\end{array}$ & \multicolumn{2}{|c|}{ Monetary transactions } & \multicolumn{2}{|c|}{$\begin{array}{c}\text { Non Monetary } \\
\text { transactions }\end{array}$} \\
\hline $\begin{array}{l}\text { Illegal } \\
\text { activity }\end{array}$ & \multicolumn{2}{|c|}{$\begin{array}{l}\text { Trade in stolen goods; drug } \\
\text { dealing and manufacturing; } \\
\text { prostitution; gambling; } \\
\text { smuggling; fraud; human } \\
\text { trafficking, drug trafficking and } \\
\text { weapon trafficking. }\end{array}$} & \multicolumn{2}{|c|}{$\begin{array}{l}\text { Barter of drugs, stolen } \\
\text { goods, smuggling, etc.; } \\
\text { producing or growing } \\
\text { drugs for own use; theft }\end{array}$} \\
\hline \multirow[t]{2}{*}{$\begin{array}{l}\text { Legal } \\
\text { activity }\end{array}$} & Tax evasion & $\begin{array}{c}\text { Tax } \\
\text { avoidance }\end{array}$ & $\begin{array}{c}\text { Tax } \\
\text { evasion }\end{array}$ & $\begin{array}{c}\text { Tax } \\
\text { avoidance }\end{array}$ \\
\hline & $\begin{array}{l}\text { Unreported } \\
\text { income from } \\
\text { selfemployment; } \\
\text { wages, salaries } \\
\text { and assets from } \\
\text { unreported work } \\
\text { related to legal } \\
\text { services and } \\
\text { goods }\end{array}$ & $\begin{array}{l}\text { Employee } \\
\text { discounts; } \\
\text { fringe } \\
\text { benefits }\end{array}$ & $\begin{array}{l}\text { barter of } \\
\text { legal } \\
\text { services } \\
\text { and } \\
\text { goods }\end{array}$ & $\begin{array}{l}\text { All do-it } \\
\text { yourself } \\
\text { work and } \\
\text { neighbour } \\
\text { help }\end{array}$ \\
\hline
\end{tabular}

Based on the explanation above, it can be drawn the difference between shadow economy and underground economy. Shadow economy includes both legal and illegal economic activities that are not transparent. While underground economy refers to illegal economic activities that are unstructured, disorganized, informal and hidden.

TABLE II. DIFFERENCE BETWEEN SHADOW ECONOMY AND UNDERGROUND ECONOMY

\begin{tabular}{|l|l|l|l|}
\hline & \multicolumn{1}{|c|}{ Praktek } & \multicolumn{1}{|c|}{ Karakteristik } & \multicolumn{1}{|c|}{ Tujuan } \\
\hline $\begin{array}{l}\text { Shadow } \\
\text { economy }\end{array}$ & $\begin{array}{l}\text { Legal and } \\
\text { illegal }\end{array}$ & $\begin{array}{l}\text { Stuctured, } \\
\text { organized, } \\
\text { formal, hidden }\end{array}$ & Tax avoid \\
\hline $\begin{array}{l}\text { Underground } \\
\text { economy }\end{array}$ & Illegal & $\begin{array}{l}\text { Unstructured } \\
\text { disorganized, } \\
\text { informal, hidden }\end{array}$ & $\begin{array}{l}\text { Avoid legal } \\
\text { restriction }\end{array}$ \\
\hline
\end{tabular}

b. processed by the writer, 2019 .

The practice of shadow economy is a trend that occurs in almost all countries, both developed, developing and poor countries. In the Anglo Saxon country which is classified as a developed country, the practice of shadow economy ranges from $9-12 \%$ of national income. While in continental European countries (developed) the practice of shadow economy ranges from $20-30 \%$ of national income. The practice of shadow economy is increasingly greater in developing countries and poor countries. In that country, the practice of shadow economy ranges between $25-40 \%$ of national income. The difference is that in developed countries, the economic shadow is triggered by high tax rates. While in developing and poor countries, the economic shadow is caused by a weak legal system (regulation and law enforcement) that is run by the state.

The practice of shadow economy caused by tight government regulations, has to do with high taxes, tight business regulations, investment and other regulations. Business people and individuals consider that strict government regulations will reduce their income, thus encouraging avoidance of existing rules. Meanwhile, the practice of shadow economy caused by a weak legal system has to do with the limited knowledge and moral damage to the state apparatus that makes laws and implements laws. Due to limited knowledge, the state apparatus in making laws are often not in accordance with the regulations above and unable to reach new problems. Not infrequently, lawmakers are trapped in the practice of buying and selling articles. The practice of buying and selling this article occurs at the national level (DPR RI) to the local level (DPRD) which has ensnared legislators [5].

This legislative moral damage also occurs in the executive circle. The executive leaders he leads often practice reent seeking to enrich themselves, gain and maintain power. In the bureaucracy, rent seeking beurecracy also takes place with economic and political motives. Bureaucracy which should be neutral and serve the needs of the community, acts as a friend of the owners of capital or crony capitalism by committing various violations of the law and loosening the application and supervision of the rules. The weakness of this legal system fosters the practice of shadow economy at various levels of national and local government in Indonesia. The practice of economic shadow in the regional autonomy regime is also caused by the lack of knowledge and ability of local officials in making regulations.

\section{DISCUSSION}

\section{A. Southeast Sulawesi: Mining Areas That Still Exist}

Southeast Sulawesi Province was established in 1964, after blooming from the South Sulawesi province. At its inception, Central Sulawesi was divided into 4 districts Kendari, Kolaka, Muna and Buton. Since the autonomy of regional expansion guidelines has experienced a significant surge, Southeast Sulawesi has become one of those who experienced the process, so that until now the territorial area has been divided into 15 districts and 2 cities. The special potential of the region in the agriculture and mining sectors, as well as the lobbying abilities of the local elites of Southeast Sulawesi in Jakarta, have strong reasons why the division of new autonomous regions in the province is growing so fast.

Southeast Sulawesi is an area in the southeastern part of the island of Sulawesi. Geographically, it is located south of the equator, extending from north to south between $02^{\circ} 45^{\prime}$ $06^{\circ} 15^{\prime}$ 'latitude and stretching from west to east between 120 $\circ 45^{\prime}-124^{\circ} 45^{\prime}$ east longitude. The total area of Southeast 
Sulawesi Province is $38,067.70 \mathrm{~km} 2$, with $74.25 \%$ in the form of sea water and $25.75 \%$ in the form of land. Demographically Southeast Sulawesi is inhabited by various ethnic groups with a population of 2,653,654 inhabitants (BPS 2019).

The agricultural sector is the main contributor to Southeast Sulawesi's GRDP of $24.08 \%$, followed by the mining sector by $21.01 \%$ (BPS, 2018). Mining potential in Southeast Sulawesi is spread across ten districts and cities including: Bombana, South Buton, North Buton, Kolaka, North Kolaka, Konawe, South Konawe, North Konawe, Muna, Bau-Bau City (Suseno and Mulyani, 2012). The wealth of the mine contained in Southeast Sulawesi attracted the attention of mining investors. Historical records show that before regional autonomy was rolled out, two large companies - PT. ANTAM (owned by Indonesia) and PT. INCO (owned by Canada and Brazil) - holds a work contract license to carry out mining activities and control large-scale mining land in Southeast Sulawesi. In the era of regional autonomy, the number of mining companies grew rapidly, recorded in 2015 as many as 528 IUP scattered in Southeast Sulawesi (ESDM, 2015). In 2018, that number will be slightly reduced - remaining 438 IUPs - as a result of the government's mining rearrangement policy. Hundreds of IUPs, if classified based on the number of workers, business capital and land tenure, can be classified in three categories: large, medium to small.

Large scale mining companies including PT. ANTAM, PT. Vale Indonesia (Ex-INCO) and PT. Virtue Dragon Nickel Indutsry (PT. VDNI). In the history of mining activities in Southeast Sulawesi, PT. VDNI is a young company established in 2014. This subsidiary of Jiangsu Delong Nickel Industry Co. (Tingkok) has an investment of US \$ 1 billion, stands in an industrial area with a land area of 2,253 Ha and is estimated to be able to absorb around 10,000 workers (Tempo, 2019). The operationalization of large scale mining companies is supported by the presence of medium and small scale mining companies. Mining products from medium and small companies, namely nickel which are still in the form of ore (logs / raw materials) are supplied / sold to large scale companies. The sale of nickel ore to large companies is a step taken, if there are no purifiers (stoves) owned by medium and small companies. This is absolutely necessary to avoid government policies that prohibit the export of nickel ore, before going through the refining process first. However, there are still a number of mining companies that violate these government policies.

The emergence of many mining companies in Southeast Sulawesi is inseparable from the still large mine reserves, especially nickel. Nickel minerals in Southeast Sulawesi Province are very abundant and are spread in North Konawe, North Kolaka, Konawe, Kolaka, Bombana, South Konawe, and Buton Regencies, with a total area of 313,788.77 Ha. Total nickel reserves in Southeast Sulawesi Province were 97,401,593,025.72 Wmt. North Konawe Regency is the district with the largest amount of nickel reserves, which is $46,007,440,652.72 \mathrm{Wmt}$ with an area of 82,626.03 Ha (ESDM, 2015). The mining potential of Southeast Sulawesi makes this area included in one of the priority industrial estates established by the central government based on Presidential Regulation No. 2 of 2015 RPJMN 2015 - 2019 was published which stipulates 14 Priority Industrial Estates outside Java.

\section{B. Central Sulawesi: New Areas of Mining Industry and Business}

Central Sulawesi is a province in the central part of Sulawesi Island which was founded in 1964, which was previously part of the North and Central Sulawesi Province. In the beginning, Central Sulawesi was divided into four districts - Donggala, Poso, Banggai and Buol Toli-toli. In the era of regional autonomy, Central Sulawesi experienced a booming regional expansion as well as other regions, so that now its territory is divided into 12 districts and 1 city. The area of Central Sulawesi reaches $61,841.29 \mathrm{~km}^{2}$, with a population of 3,222,241 people (BPS, 2015). This acquisition also placed Central Sulawesi as the largest area among all provinces on Sulawesi Island, and has the second largest population on Sulawesi Island after South Sulawesi.

The agricultural sector is the main supporter of the economy of Central Sulawesi. In 2017 the GRDP contribution of the agricultural sector was $28.92 \%$, followed by other sectors $24.47 \%$, mining $12.83 \%$, construction $12.50 \%$, industry $12.34 \%$ and trade $8.94 \%$. (BPS, 2018). Although the agriculture sector is a major contributor to Central Sulawesi's GRDP, over the past three years (2015-2017) the contribution of this sector has tended to decline, on the other hand the mining sector, which was in the fourth position, managed to rise in the third position to shift the construction sector. The GRDP growth of the mining sector in Central Sulawesi is related to the presence of mining companies that carry out mining and processing of mining products, including PT. International Morowali Industrial Park along with a number of its subsidiaries.

In terms of mine content and historical aspects, the presence of mining companies in Central Sulawesi is minimal, compared to Southeast Sulawesi. Noted, the natural content of Central Sulawesi is petroleum and nickel, and even then it is very limited. However, the existence of a nickel mine had taken place before regional autonomy, where PT. INCO (now PT.Vale Indonesia) is the only mining company that has long held a mining work contract in Central Sulawesi. PT. INCO is located around the borders of Central Sulawesi, South and Southeast Sulawesi, namely Morowali and North Morowali Regencies. The nickel content in Morowali and North Morowali is the largest in Central Sulawesi, but not greater than the nickel content in Southeast Sulawesi. Thus the mention of Central Sulawesi as a mining-producing area is 
less precise, on the contrary the more suitable term is a new area of mining industry and business.

The popularity of Central Sulawesi as a new area of business and the mining industry can be seen from the growth in the number of mining business permits in the era of regional autonomy, where as of 2017 the number of IUPs in Central Sulawesi has reached 437. At the same time in 2015 the central government policy that sets priority industrial areas outside Java based on Presidential Regulation No. 2 of 2015. Through the Perpres, Central Sulawesi (Morowali) became one of the priority industrial development areas in the mining sector. The choice of the mining sector as an industrial type developed in Morowali has its own advantages. From a geographical location, Morowali is on the coast, making it easier for the export process. In addition, Morowali has a close location with the Province of Southeast Sulawesi as a producer of nickel in large quantities.

The mining content and government policies have stimulated the arrival of investors, which is marked by the emergence of a national nickel company and a multi-national corporation (MNC) in Central Sulawesi. MNC's nickel company which is quite well known is Indonesia Morowali Industrial Park (IMIP) as the largest nickel company in Indonesia with an authorized capital of 40,000,000 USD. The shareholders of PT. IMIP is Shanghai Decent Investment (Group) of 49.69\%, PT. Sulawesi Mining Investment 25\%, and PT Bintangd eight Investama as much as $25.31 \%$. PT. IMIP houses at least 16 companies and employs approximately 31,000 people by the end of 2018 .

In addition to international companies, national and local companies are present to take advantage of investment opportunities in Morowali. Large-scale national companies including PT. Central Omega Resource Tbk (PT. COR). The company is in charge of 6 subsidiary companies, namely PT. Mulia Pasific Resource (MPR), PT. Mega Buana Resource (MBR), PT. Itamatra Nusantara, PT. COR Industri Indonesia, PT. Macrolink Omega Adiperkasa, PT. Bumi Konawe Abadi. The existence of a mining company in Morowali according to information compiled by the Central Sulawesi Mining Community Network is owned and supported by elites, local elites and former military. A number of names such as Tommy Winata (national businessman), Viktor Laiskodat (Nasdem Politician / NTT Governor), Ahmad Ali (Nasdem Politician / Member of Parliament), Sintong Panjaitan (former Kopassus Danjen), Anwar Hafid (Democratic Politician / Former Morowali Regent) - is said to have a mining company in Morowali.

The presence of ex-military in the mining business and industry in Central Sulawesi gave rise to the name Bintang Delapan as one of the shareholders of PT. IMIP. Information obtained from JATAM Central Sulawesi, stated that behind the name of the company, the term Bintang Eight by activists often referred to it as a mining company supported by eight generals. Based on reports from Christopel Paino and Sapariah Saturi, there was the name of Lt. Gen. Purn. Sintong Panjaitan (former Kopassus Danjen) as President Commissioner of the Bintang Delapan Group and Maj. Gen. Purn. Hendarman Supandji (Former Danpuspom) as President Commissioner of PT. Bintang Delapan Investama [6]. Meanwhile, to identify six other generals is difficult to prove. Two other generals who are often mentioned in civil society and in media coverage are General Luhut B. Panjaitan and Lt. Gen. Purn. Prabowo Subianto as pembeking the Bintang Delapan. However, the two generals' last names are difficult to prove. Luhut's presence seemed to only represent the government as an investment party. While based on media searches East Tribun, Tirto news. Id and detik.com involvement of Prabowo Subianto in PT. Bintang Delapan not found [7].

Previously, based on the Mining Society Network report, the involvement of former Generals in the mining business was a scene that was frequently encountered. The JATAM investigation report titled Mining Oligarchy in the Presidential Candidate Contest mentions the Generals involved in the mining business, namely General Retired. Luhut Binsar Panjaitan as the owner of the Toba Sejahtera company which explored the mine in Kalimatantan, General Ret. Fahrul Rozi as Commissioner of Toba Sejahtera and commissioner of PT. ANTAM, Lieutenant General. Purn Suaidi Marasabessy Director of PT. Kutai Energi, Lt. Gen. Purn. Prabowo Subianto owns Nusantara Energy Resource (JATAM, 2019). The involvement of ex-military in business is rather difficult to categorize as a group of professional entrepreneurs, given that their careers are mostly spent in the military and not as professional entrepreneurs. On the contrary, their involvement appears to be more influenced by their expertise in presenting a sense of security and the ability to organize violence that might threaten the survival of professional business people. This military and business alliance extended the practice that often occurred during the New Order era, including the Eighth Joint Committee (Kodel) established by Soegeng Suryadi, which included the name of General Ponjto Sutowo.

\section{Shadow Economy Practices Mining in Central and Southeast Sulawesi}

In the last ten years, mining activities have been able to significantly increase the GRDP of Southeast Sulawesi and Central Sulawesi as mining producing areas and mining industry areas. Mining activities in the two provinces have succeeded in opening up employment opportunities. Local workers, outside the region to foreign workers is a scene that is often found in observing labor activities in the mining company PT. IMIP (Morowali, Central Sulawesi) and PT. VDNI (Konawe, Southeast Sulawesi). The presence of mining companies, slowly changing the remote area (rural) which has a small population, into a city that has a population density. 
Mining activities have slowly changed the livelihoods of the population, which used to depend on the agriculture and marine sectors, are now beginning to shift to the mining industry sector. The area that used to be a slow economic cycle, has now become the center of a new economy. Around mining companies that have been operating, a number of small businesses are growing rapidly, such as boarding houses, food stalls, shopping places.

The economies of Southeast Sulawesi and Central Sulawesi can grow even better, if mining governance is carried out properly (free of corruption). The KPK study stated that corruption in the Minerba mining sector resulted in significant state losses, reaching 372,065,070.86 USD. Of that amount, nickel mining accounted for the largest loss of 15,413,941.95 USD (KPK, 2014: 122). The KPK noted that mining sector corruption included: arrears in payment of nontax state revenues (PNPB), tax evasion, potential for unexplored taxes, sale of illegal mining products to environmental damage. Shadow economy practices in the mining sector occur throughout Indonesia, including Southeast Sulawesi and Central Sulawesi.

Peta Sebaran IUP Se-Indonesia dan Identifikasi NPWP

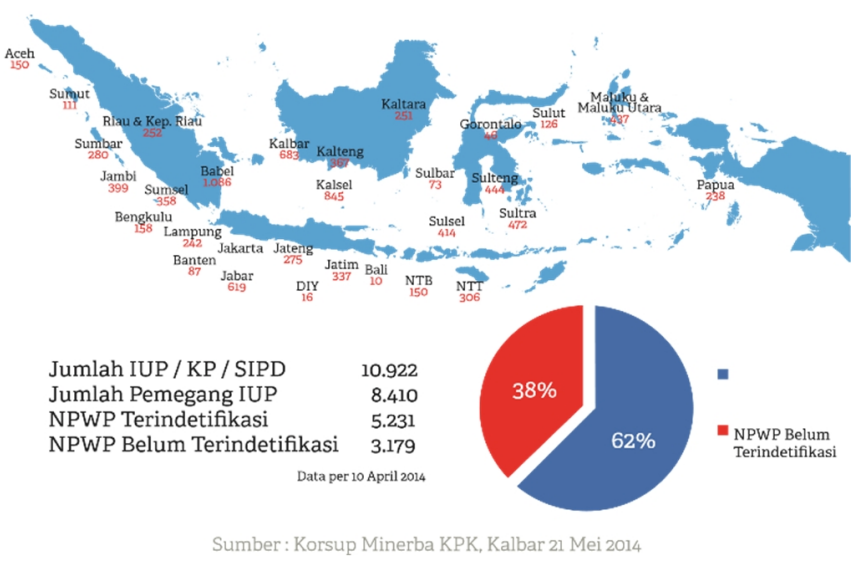

Fig. 1. Example of a figure caption. (figure caption)

For this reason, the government made efforts to arrange development activities that began with the birth of Law no. 4 of 2009 concerning Minerals and Coal (MINERBA). After the MINERBA Act was enacted, the Ministry of Energy and Mineral Resources undertook reconciliation efforts with local governments to validate the IUPs that had been issued. The validation results categorize permits into two statuses, namely: Clean and Clear $(\mathrm{CnC})$ and non-Clean and Clear (non-CnC). ${ }^{2}$ Periodically, IUP validation efforts are continuously updated and evaluated as shown in the following table:

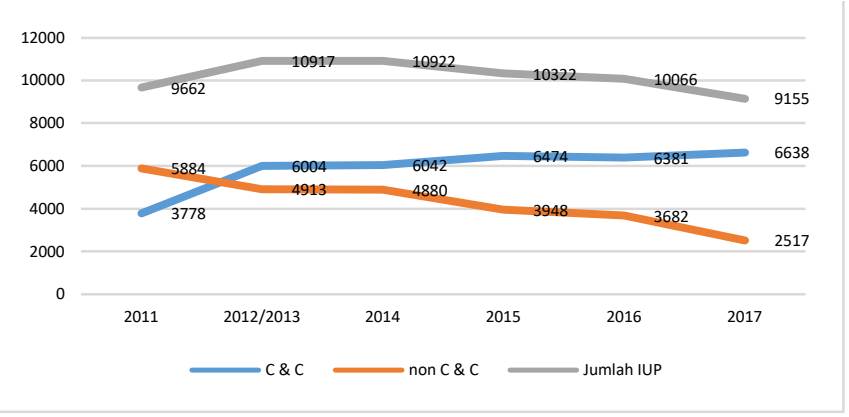

Fig. 2. Trends in the development of CNC and non-CNC IUPs (20112017). (PWYP, 2017)

Based on the picture above shows the trend of decreasing the IUP of non-CNC categories. This is a positive achievement, although it requires improvement considering mining activities present many losses, both in terms of environmental aspects and state revenue. The coordinated report of the Corruption Eradication Commission (KPK) identified state losses in mining management in Indonesia, including [1]: 1). Losses in non-tax state revenue (PNBP); 2). Arrears on PNBP payments from mining entrepreneurs; 3). There is an IUP that does not have a TIN; 4). There are IUPs that do not submit SPT reporting; 5). The low fulfillment of the reclamation obligations and social responsibility of the mining company. State losses due to mining will be even greater if accumulated with environmental damage. According to data compiled by Kompas, as much as $70 \%$ of environmental damage comes from mining operations [8].

\section{Environmental damage around the mining area}

Mining activities although able to move the regional economy, but behind that it is a number of environmental damage issues. Since the operation of a number of mining companies, residents around the mine have begun to complain about environmental pollution, water, air and land. PT Central Omega Resources Industri (CORII) 's activities in North Morowali have caused clean water as a source of livelihood for the residents to be mixed with mud [9]. Not to forget the coast of Morowali which used to be blue sea has become yellow sea. The area of the yellow ocean is expanding when the rainy season arrives. Rain water sourced from the mountain flowed swiftly without being overpowering and submerged a number of residents.
${ }^{2} \mathrm{CnC}$ IUP is an IUP whose issuance process complies with statutory provisions and does not have administrative and overlapping territorial and commodity issues. On the contrary, Non-CnC IUPs are IUPs that have problems in the issuance process and / or have overlapping territorial issues. 


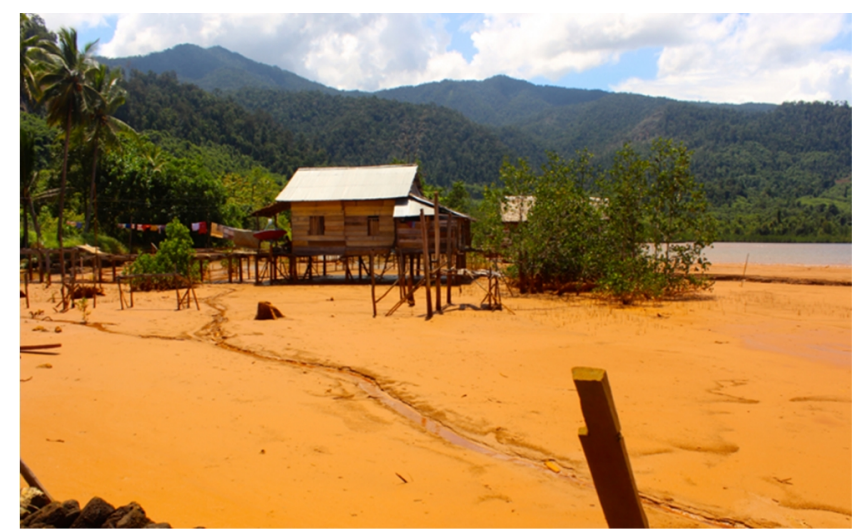

Fig. 3. Enviromental pollution in the North Morowali coast. (Jatam Central Sulawesi)

As a result of the mine, at the beginning of June 2019, flash floods hit Sulawesi, which cut off the roads and bridges that connect Central Sulawesi and Southeast Sulawesi, submerging settlements in Morowali, North Konawe and Konawe [10]. A mining company, General Sumber Mining Indonesia (GSMI), an Aneka Tambang subsidiary that has been operating for nine months in Petasia District, Morowali Regency, has damaged the environment and livelihoods of the local community. In addition, PT GSMI is a company that piles up a port runway in the middle of the Ganda-Ganda Village settlement which makes dozens of fishermen unable to enjoy the results of their business at the "Karamba" location [11]. In addition to flooding and water pollution, residents also complained of air pollution due to mine dust.

A similar scene can also be seen in Southeast Sulawesi, the North Konawe region where a number of legal and illegal mining companies operate each time rain arrives as a flood subscriber, the color of river water and seawater is almost indistinguishable due to siltation and mining waste which carries out mining activities at the peak of the mountain, mountain slopes to the coast. The mine in North Konawe has transformed the green areas of the wilderness into a mining company settlement which from a distance looks brownish yellow. No wonder then, at the beginning of June 2019, the floods hit the North Konawe Regency (Konut), Southeast Sulawesi Province. According to local government records, the flood in 2019 was the worst flood since 42 years.

According to North Konawe District Government data, the floods in 2019 submerged 6 sub-districts and 28 villages. As a result, thousands of residents from 1,054 families were forced to flee. In addition, flooding also submerged 1,484 hectares of agricultural, plantation and fisheries land in North Konawe. Four elementary school units, one secondary school unit, and one puskesmas. Not only that, the Trans Sulawesi route in Konut that connects Southeast Sulawesi and Central Sulawesi was paralyzed due to the breakup of the Asera
Bridge. The bridge also connects several sub-districts in Konut. The bridge's breakage practically made several subdistricts, such as Oheo, Wiwirano, Langgikima, and Landawe districts isolated [12]. The news of a national media said that there was a mining company contribution behind the North Konawe flash flood [13].

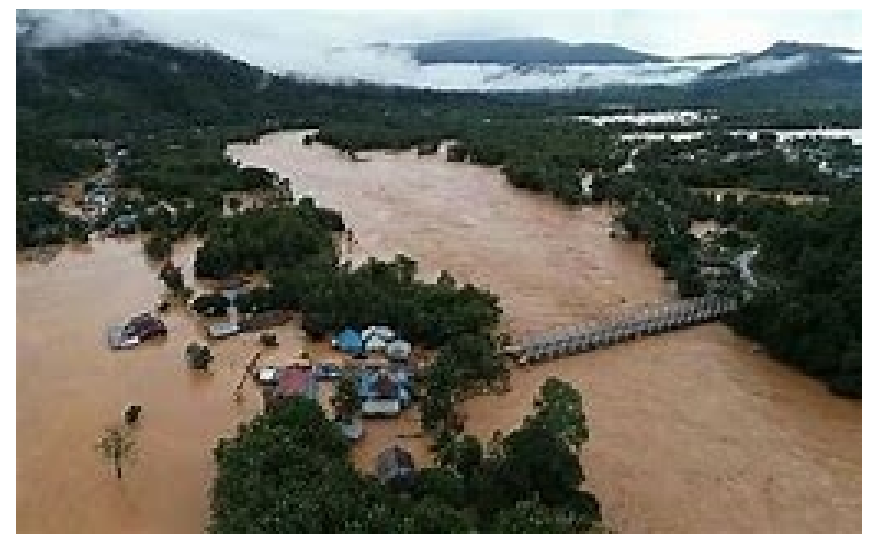

Fig. 4. Flood disaster in North Konawe Regency. (cnnindonesia.com)

\section{CONCLUSION}

Mining activities in Southeast Sulawesi and Central Sulawesi in the era of regional autonomy had a positive impact on the local economy, especially micro-economics (UKM). The mine is able to change what was once a remote area into a new urban area. The presence of mine workers is able to move the local economy and society. Even so, mining has also made the lives of local communities uneasy, this is related to environmental damage and pollution that haunts their homes. Flooding, water pollution from mining waste, air pollution from dust from mining activities is an event that is often experienced by people who live in the mining areas of Southeast Sulawesi and Central Sulawesi. In addition, mining in Central and Southeast Sulawesi still discusses a number of issues that do not benefit the country, this is related to the number of illegal mining companies, tax evasion, illegal mining material sales, illegal foreign labor is often found in mining activities. Therefore the government needs to improve the governance of mining policies, so as to provide better benefits for the community, government and the business world..

\section{ACKNOWLEDGMENT}

This paper was inspired by our trips in Central Sulawesi and Southeast Sulawesi, along the way we witnessed mining activities instantly turning villages into cities, turning 
mountains into valleys, turning blue seas into yellow seas. Our gratitude goes to the environmental activists of the Central Sulawesi Mining Community Network (JATAM) and the Southeast Sulawesi Forum for the Environment (WALHI), which provided much information on the completion of this article.

\section{REFERENCES}

[1] KPK. Laporan Koordinasi dan Supervisi Sektor Pertambangan Mineral dan Batubara : Temuan-Tindak Lanjut-Capaian. Publish What You Pay Indoensia, 2017.

[2] Chotim, Erna Ermawati, "Ruang-Ruang Sosial Pekerja Ekonom Bawah Tanah (Underground Economy)". Journal Sosiologi Masyarakat, Vol. 15. No. 1, Januari 2010, hlm 87-89.

[3] Dell'Anno, R. (2003), 'Estimating the shadow economy in Italy: a structural equation approach', Working Paper 2003-7, Department of Economics, University of Aarhus.

[4] Schneider, Friedrich \& Williams, Colin C. 2013. The Shadow Economy. London: The Institute of Economic Affairs.

[5] https://kumparan.com/@ kumparannews/mahfud-md-beberkanmodus-jual-beli-pasal-uu-di-dpr-1qtnzRwkcqc
[6] https://www.mongabay.co.id/2018/04/30/ketika-pabrik-smelterdatang-warga-morowali-utara-tertimpa-beragam-masalah-ini/

[7] http://makassar.tribunnews.com/2018/05/05/bukan-milik-prabowoinilah-daftar-orang-hebat-di-balik-pt-bintang-08-yang-diserbu-tkachina-aaa?page $=4$

[8] https://regional.kompas.com/read/2012/09/28/17313375/70.Persen.Ke rusakan.Lingkungan.akibat.Operasi.Tambang

[9] https://www.mongabay.co.id/2014/05/12/fokus-liputan-morowali-dibawah-cengkeraman-tambang-para-jenderal/

[10] https://news.trubus.id/baca/29102/eksploitasi-sumber-daya-alamdiduga-penyebab-banjir-di-kabupaten-morowali

[11] http://pergerakan.org/perusahaan-tambang-rusak-lingkungan-dikabupaten-morowali-sulawesi-tengah/

[12] https://kumparan.com/kendarinesia/banjir-konawe-utara-pada-2019terparah-sejak-42-tahun-terakhir-1rGJVpozLOF

[13] https://tirto.id/ada-proyek-tambang-di-balik-banjir-bandang-konaweutara-eci1

[14] https://tirto.id/benarkah-pt-bintang-8-mineral-milik-prabowomayoritas-pakai-tka-cJ8c

[15] https://news.detik.com/berita/d-4006253/profil-pt-bintang-delapanyang-dikaitkan-dengan-prabowo 